\section{ALEXANDER BRAUN}

WE regret to announce the death of the well-known. German botanist, Prof. Alexander Braun, which took place at Berlin, on March 29. He was born in Ratisbon, May ro, 1805 , and after the completion of his university studies entered upon the duties of Professor of Botany in the University of Freiburg, in Baden. Here he published his first important book, "Vergleichende Untersuchung über die Ordnung der Schuppen an den Tannenzapfen," in which he formulated the theory with regard to the position of the leaves on plants now essentially recognised by botanists. In $185^{\circ}$ he accepted a call to the University of Giessen, and issued shortly after his most notable work, "Betrachtungen über die Erscheinung der Verjuingung in der Natur, insbesondere in der Lebens- und Bildungsgeschichte der Pfanze." The extensive series of observations, and the numerous valuable theoretical deductions recorded in this suggestive work, formed one of the most noteworthy contributions to vegetable morphology, and placed the author at once among the leading botanists of the day. In 1852 he removed to Berlin, where he had been appointed Professor of Botany and Director of the Botanical Gardens, positions which he occupied up to the time of his death. The unwearied activity of Braun during this period is evidenced by the large number and variety of the contributions made by him to botanical literature. Of these his investigations on cryptogamia assume the foremost rank, embracing papers on the families Marsilia, Pilataria, and Selaginella, African varieties of Chara, Movernents of the Juices in the Cells of Char a, Vegetable Individuals in their relations to Species, Some New Diseases of Plants caused by Fungi, New Varieties of Single-celled Algæ, \&c.

Among his more prominent publications on phanerogamia should be mentioned the papers on parthenogenesis, polyembryony, and budding of cclebogyne, and the oblique direction of woody fibre in its relations to twisted tree stems. His efforts in all investigations were chiefly directed to perfecting our knowledge of vegetable morphology, and by comparative studies in this region, to the establishment of well-defined. laws with regard to the growth of plants, and the relationship between different varieties. Braun's theories on the latter subject led to the formation of a system, which, although not accepted in all points, is yet regarded by many botanists as the most perfect approach to a natural classification of plants which we at present possess. A contemporary botanist describes the leading feature of his character as consisting in an "earnest striving to bring all the widely diverse families of the vegetable kingdom, fossil as well as existing, within his grasp, and by means of thorough, comparative study to advance toward the true natural classification."

The merits of Prof, Braun were recognised by the bestowal of numerous German orders, and from the King of Prussia he received the title of "Geh.-Regierungs-Rath." He was a prominent member of the Berlin Academy of Sciences and the Botanical Society, occupying the presidency of the latter for a number of years. His papers appeared chiefly in the Transactions of these two societies; the classification of plants being given, however, in Ascherson's "Flora of the Province of Brandenburg," in 1864 .

\section{THE LOAN COLLECTION OF SCIENTIFIC APPARATUS}

THE last of the "present series" of free lectures in connection with the Loan Collection of Scientific Apparatus was given on Saturday, in the lecture theatre of the South Kensington Museum. Major Festing, R.E., took the chair, and the theatre was, as usual, crowded.
The lecture was given by Mr. W. Stephen Mitchell, M.A., on "The Challenger Soundings and the Lost Island of Atlantis." An abstract of this will shortly appear. At the end of the lecture Mr. Mitchell saic he thought that as this was the last-at any rate of this series-it would be in accordance with the wish of the audience that a few words should be said by way of résumé, to mark the occasion. He regretted that his place was not occupied by some one eminent in science. When the Loan Collection of Scientific Apparatus was opened there were planned in connection with it conferences, demonstrations, lectures to science teachers, and the free evening lectures. The conferences lasted as planned during May and June, the lectures to science teachers were carried out as proposed, and the demonstrations were given till December $3 \mathrm{r}$. At that date, in consequence of packing the cases for returning the collections lent from abroad, which were lent for a definite period only, it was necessary to close the galleries to the public. The free lectures, however, had been continued, and the apparatus from the galleries had been brought into that theatre, as it had been found necessary, to illustrate the lectures. The lectures had thus kept up the continuity of the collection. He believed he was right in saying that from the outset the promoters of the Loan Collection had looked forward to the establishment of a permanent physical science museum somewhat in imitation of the Conservatoire des Arts et Métiers of Paris. Such a museum was recommended by the Royal Commission on Scientific Education, under the presidency of the Duke of Devonshire, and composed of some of the most distinguished men of science in this country. For a building to contain such a musenm the commissioners of tha $\mathrm{Ex}$ hibition of $185 \mathrm{I}$, under the presidency of the Prince of Wales, have voted $100,000 \%$, and offered it to the Government. A petition in favour of the establishment of such a museum bad, since the opening of the collection, been signed by officers and fellows of learned societies, and presented to the Duke of Richmond and Gordon. At this last lecture of the series they would naturally ask what was likely to be done for the future. As he was in no way officially connected with the muscum he was not in a pusition to give any certain information; but this much he could tell them, a number of instruments that would otherwise have been returned had been acquired by purchase, a number had been presented, a number were left on loan for an indefinite period, and many were left under certain conditions. The galleries at the present time contained a collection of fair size to commence a permanent collection. Here, as in considering the lost island of Atlantis, they must be careful to discriminate between facts and inferences to be drawn from facts. No announcement had been made by the Government as to its intentions. The present condition of the Collection, as he had stated it, was a fact, and they would draw for themselves inferences as to what this might mean. He had seen a statement that the permanent museum mignt be open in May, but he could not say how far this represented official intentions. The crowded audiences at the lectures in that theatre was, he said, a proof that they wished the Collection and the lectures in connection with it to continue.

Mr. F. S. Mosely moved, and Mr. J. Heywood, F.R.S., seconded the following resolution:- "We who form the audience at this, the last of the present series of lectures in connection with the Loan Collection of Scientific Apparatus, desire to thank the Board of the Science and Art Department for having arranged this series of lectures. We would wish to take this opportunity to express the hope that the Loan Collection of Scientific Apparatus may lead to a permanent collection of a similar nature. We beg the chairman to convey the terms of this resolution to the head of the department." 
The motion was put to the meeting and carried unanimously with loud applause.

Major Festing said that, as representing the department, he was sorry he could give no more information than the lecturer had. The Government had not yet announced its intention as to what it would do in the matter. It had lately had many other matters on hand. With regard to the lectures, it was felt that it was hardly fair to continue to ask men of science to give their services gratuitously, and until some arrangement for fees could be made, he thought the lectures would probably remain in abeyance. It would give him pleasure to forward the resolution so unanimously carried to the head of his department as requested.

\section{THE DEVELOPMENT OF BATRACHIANS WITHOUT METAMORPHOSIS}

IETAMORPHOSIS, or the transition of the animal through an intermediate stage between the ovum and the adult, has hitherto been considered by modern naturalists a special characteristic of the Batrachians amongst the Vertebrates, and as one of the main features which disinguish them from the true Rep tiles, with which they were formerly united. It is, therefore, surprising to learn, as we do from a recent com munication of Dr. Peters to the Royal Academy of Sciences of Berlin, that there are cases in which no such metamorphosis takes place, and the young frog is deve. loped directiy from the egg without showing any signs of what is usually called the "tadpole" stage.

Dr. Peters's noteworthy discovery is based upon observations made by Dr. Bello, Herr Krug, and Dr. J. Gundlach, in Porto Rico, on the development of a West Indian tree-frog-Hylodes martinicensis, which seems to be not uncommon in Porto Rico, and is there gererally known by the vernacular term Cogui.

Five years ago Dr. Bello stated ${ }^{1}$ that a tree frog in Porto Rico called Coqu was remarkable from the fact that the young came out of the eggs in a perfect condition, and fit for life in the air. "In I 870," he says, "I observed in a garw den an example of this species upon a liliaceous plant, on which about thirty eggs were clustered together in a cotton-wool-like mass; the mother kept close to them as if she intended to incubate. A few days afterwards I found the little frogs from two to three lines long just born, with all their four feer perfectly developed, springing about, and enjoying life in the air. In a few days they attained their full size. This garden is surrounded by walls six feet high, and there is no water in it. The soncalled lily (which appears to be an introduced species of Crinumn) always contains a little water in the receptacles, but is not a water-plant."

The translator of these observations rightly remarks that the exclusion of the animal out of the egg was not actually witnessed in this case, and that it was possible even in the short time which elapsed between when the eggs were seen and the young frogs appeared, some metamorphosis might have taken place, especially as the subsequent development seems to have been uncommonly quick.

These short observations of Dr. Bello appear to have attracted the less attention inasmuch as the development of tree-frogs from eggs placed in dry situations in frothy masses had been already observed and described in tropical countries. In 1867 Herr Hensel published some interesting observations on Cystignathus mystacinus, in the forests of Rio Grande do Sul, ${ }^{2}$ and last year Dr. Peters laid before the Academy of Berlin the extraordinary discoveries of Buchholz concerning the egg-masses of Chironantis gwineensis laid upon trees in Guinea. Be-

1"Zoologische Notizen aus Portorico," in "Der zool. Garten," $r 8_{75}$,

p. 35 s. pt. x, p. I29. sides this the development of Alytes obstetricans between the hind-legs of the male in the ordinary way, and, through Herr Weinland's brilliant investigations, the metamorphosis of the young in the dorsal sacs of the females of Opisthodelphys and Nototremo, were facts so generally known that it seemed highly improbable that any Batrachian should be developed without metamorphosis.

Under these circumstances it is of the greatest interest to be able to state that Dr. Bello's information has been fully corroborated by recent observations of Dr. Gundlach and by preparations which he has transmitted to Berlin.

"On May 24, I876," Dr. Gundlach says, "I heard a singular call like that of a young bird, and went to see what it was. Between two large orange-blossoms I perceived a leaf $f$ rog, and on taking hold of it, found $I$ had captured three males and a female of the Cogut. On putting them into a damp glass, one of the males quickly placed himself on the female and grasped around her. Not long afterwards she had laid from fifteen to twenty eggs, which, however, mostly soon disappearedperhaps eaten.

"There were subsequently laid five eggs, round, with a transparent covering, which I removed and placed on sone wet slime. The inner yelk, of a whitish or pale straw colour, contracts a little, and then the tail is seen forming.

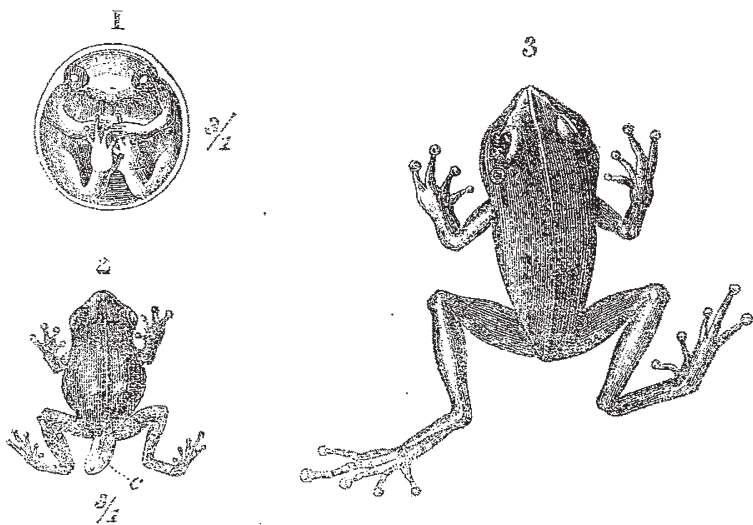

Tig. T.-Egg of Hylodes Mrrinticensis, twelve days old, lower surface FiG. 2,-Young of Hylodes as it leaves he egg; 6 , tail. FiG. 3.-Aduit male Hylodes, natural size.

In eight days this was quite clearly visible, as well as the eyes, and the red pulsating blood-vessels. Later on traces of the legs became manifest. I was now absent for some days, and when I returned, on June 6, found the eggs still, but on the next norning, the young were out, and had no trace left of the tail.

"Afterwards I found between two leaves of a large Amaryllid, just like Dr. Bello, a batch of more than twenty eggs, upon which the mother was sitting. I cut off the leaf, along with the eggs-upon which the mother jumped off-and placed them in a glass with some damp earth at the bottom. About the fourteenth day, having returned from an excursion, I found, at 9 A.M., all the eggs hatched, and I remarked on the young ones a little white tail (see Fig. 2,c), which by the afternoon had altogether disappeared."

Dr. Gundlach's collection, as Dr. Peters tells us, contains four eggs of this frog, with embryos. They consist of a transparent vesicle of from 45 to $5.5 \mathrm{mill}$. in diameter, which is partly occupied by an opaque flaky white mass. The vesicle is tilled with a trans parent fluid, which allows one to see every part of the swimming embryo quite clearly. The embryo, as in the case of mammals, is curved together on the lower surface, so that the head approaches the lower extremities, which, as well as the anterior extremities, are drawn together under the belly and lie close to the body. 